\title{
ANALYSIS ON APPLICATION OF CHLORELLA IN THE FEEDING OF FARM ANIMALS
}

\section{Kateryna Garbazhii ${ }^{1}$}

DOI: https://doi.org/10.30525/978-9934-588-15-0-131

Abstract. Today the problem associated with rational feeding of farm animals is relevant and requires the new approaches and technologies satisfying the natural need of animals for food without using expensive fodders at the same time that determines the chosen theme of this article. The purpose of the paper is to summarize and analyze data related to chlorella application in feeding of farm animals. The object of current research is alga of chlorella and its forms including suspension, extract and dry paste. The research consists of introduction and five parts that explain the action of chlorella on farm animals in particular on physiological and productive functions, immune system. The first part provides the modern information about the current state of feeding industry in order to determine the main its problems including ignorance of digestion and metabolism of farm animals and increase of feed costs. Determination of chemical composition of chlorella as critical factor of using it in feeding of farm animals is the aim of second part. According to investigations written by a large number of scientists chlorella has the biochemical composition with high value due to presence of protein, carbohydrates, lipids, aminoacids, vitamins and trace elements. The physiological and productive action of chlorella in feeding of farm animals shown in third part of monography is manifested in increase of the indices of live weight gain, animal body resistance, improvement of reproductive functions, and the chemical composition of meat. Chlorella use as a source of pigments and trace elements for farm animals is proved by major of researchers whose works are analyzed in fourth part. Different forms of chlorella using contain pigments, which synthesize the enzymes necessary for normal metabolism of living organisms embracing chlorophyll, a wide

\footnotetext{
${ }^{1}$ Candidate of Agricultural Sciences, Associate Professor, Assistant Professor of Department of Commodity Research and Customs MATTERS, Deputy Dean of the Faculty of Food Technology and Food Science, Odessa National Academy of Food Technologies, Ukraine
} 
range of orange and yellow carotenoids. In addition, in specific conditions chlorella can accumulates such important trace elements as $\mathrm{Se}$ and $I$ that will be able to prevent of a number of diseases, including malignancies, thyroid gland dysfunction, cardiovascular disease, neurological diseases, aging, infertility and infections of farm animals. The next part of monography provides data about effect of chlorella using on immune system of farm animals namely the aqueous extract of chlorella promotes tissue regeneration, growth and cell division, stimulates leukocyte production and phagocytic activity, and contributes to the production of antibodies that produce lymphocytes. Also the extracts based on alga have probiotic activity influencing the composition and activity of the microflora of the gastrointestinal tract of farm animals. Consequently, introduction of chlorella in the diet of farm animals is proved to be able to help to improve their physiological and immune systems and increase of meat production simultaneously.

\section{Introduction}

Obtaining environmentally friendly and completing products from farm animals requires the constant improvement of feed technology, selection of the right diet, study of physiological needs of animals.

The full feeding is known to be one of the most important conditions formed the level of productivity in livestock. However, the value of feeding rations depends not only on the presence of all essential substances in them, but also on the degree of bioavailability of each of them. To obtain maximum productivity, reduce the cost of livestock production and to realize the genetic potential of the animal's organism farmers should use the high-quality and high-grade compound feed, including the various biologically active substances [1, p. 365; 2, p. 158].

Besides the basic nutrients functioned the plastic and energy material, the presence of a wide range of compounds with high biological activity including vitamins, macro and microelements, enzymes and many others are required in the feed rations of animals. According to investigations these components have very low concentrations in the feed composition, but play the significant role in the metabolic processes in the animal body and directly affect the absorption of the diets themselves [3, p. 65; 4, p. 15; 5, p. 125].

Therefore, balanced feeding based on the nature of the plant, a new planktonic strain of microscopic algae of chlorella, which, due to its com- 
position, has a very high biological value $[6$, p. $148 ; 7$, p. 7725]. Chlorella has the following biochemical composition (in $\%$ of dry biomass): protein $55 \%$, lipids $12 \%$, carbohydrates $25 \%$, and ash $8 \%$ [8, p. $528 ; 9$, p. 35]. Some scientists suggest that the total protein content of mature $C$. vulgaris is $42-58 \%$ of dry biomass $[10$, p.498; 11, p. 136]. Chlorella protein is superior in quality to known plant proteins, as it contains all the necessary amino acids, including essential ones [12, p. 212; 13, p. 238]. Starch is the most common polysaccharide in chlorella [14, p. 1059]. In addition, one of the most important polysaccharides present in chlorella is $\beta 1-3$ glucan $[15$, p. 166], which has numerous beneficial health and nutritional properties. The richness of vitamins of chlorella exceeds all plant feeds and crops of agricultural production [16, p. 77]. Vitamins $\mathrm{D}$ and $\mathrm{B}_{12}$ are not produced by plants, but they are contained in chlorella. The content of vitamin $\mathrm{C}$ in chlorella corresponds to its content in lemon, and unlike higher plants algae contains vitamin A in its pure form. Inositol is found 1.5 times more, biotin -2 times more, pantothenic acid - 1.3 times, paraminobenzoic acid 2.9 times more in chlorella cells than in yeast (a rich source of vitamins) $[17$, p. 14]. Thus, the addition of chlorella to the diet of farm animals will fill the deficiency of amino acids, vitamins, minerals and trace elements.

The possibility of obtaining such feed additives with low cost in the own conditions, in the presence of high efficiency of its application, puts it out of competition not only in all major economic parameters, but also in the environmental purity and quality of the animal products obtained [18, p. 729]. Moreover, using of chlorella suspension in animal husbandry is known as a vitamin-feed additive and a preventive agent [19, p. 259]. Thus, the aim of current work was the following statements:

1.to analyze the current state of feeding industry in order to determine the main its problems;

2. to clarify the reasons of chlorella using in feeding of farm animals based on alga composition;

3. to defense chlorella effect on physiological and productive functions of farm animals including sows, piglets and poultry;

4. to analyze the chlorella use as a source of pigments and trace elements for farm animals;

5. to determine the effect of chlorella on the immune system of farm animals. 


\section{Materials and methods}

In order to obtain the abovementioned answers analyzing of the scientific and practical literature was decided. To our knowledge, in scientific sources there is not sufficient number of articles published about chlorella composition and its effect on farm animals embracing the whole completed state of its alga in agriculture science. Therefore, the chosen direction of research is relevant and requires the comprehensive analysis based on proved facts. Different databases were used to find the necessary information.

\section{Research results}

\subsection{The current state of the feed base and characteristics of its compound and additives for feeding of farm animals}

The introduction of intensive development of industrial poultry and pig production depends, first of all, on the complete feeding of animals, which, in turn, depends on the quality composition of compound feeds. The main task of compound feeds is to provide the physiological need of energy for animals, nutrients and biologically active substances. It is known that compound feeds are distinguished by sources of production, chemical composition and nutrition [20, p. 88]. The number of compound feed formulations increases every year, both in Ukraine and around the world. The leader in animal feed production for 2017 is China (187 million tons per year), the United States of America (US, 170 million tons) and Brazil (69 million tons) [21].

However, scientists have concluded that the use of uniform feed adversely affects the natural resistance of the animal body, which leads to various pathologies, diseases, reduced productivity and efficiency of the industry as a whole $[22$, p. 22]. It is expected that the production and consumption of pork and poultry meat will increase by $70 \%$ in the period 2000-2030 and $120 \%$ - in the period 2000-2050 [23, p. 158].

Currently, world meat production has quadrupled from 84 million tons in 1965 to 330 million tons in 2017 [24]. According to the International Assessment of Agricultural Knowledge, Science and Technology for Development (IAASTD) [24], this tendency will continue due to the inclusion of a large number of semi-finished meat products that so-called "Western diet" of people in North America and Europe in the diet of urban middle-class in China and other countries with developing economies. 
Also, according to calculations by the United Nations Environment Program [24], the calories lost while feeding animals, instead of using them directly as food, could theoretically provide an additional 3.5 billion people. The calorie conversion factor for plant-based calories for animals is: ideally, two kilograms of grain is needed to produce one kilogram of chicken, four kilograms - per pound of pork, and seven kilograms - per kilogram of beef [25].

Statistical estimates from the Food and Agriculture Organization of the United Nations show [26] that the number of chickens breed for human consumption increased from 4.4 to 22.7 billion between 1966 and 2016 . In the same period, the number of pigs increased by $92 \%$ and accounted 981 million heads. According to the consulting company IBIS World [26], in the United States of America over the past five years, the livestock feed industry has declined by $3.2 \%$ with revenue of 33 billion American dollars in 2017. At the same time, the number of enterprises increased by $0.6 \%$ and the number of employees decreased by $1.2 \%$. All of these facts are related to a global decrease in prices for poultry and pig feeds, on average by $4.6 \%$ and $13.4 \%$, respectively [27]. However, according to market analysis by experts, this does not solve the main tasks of the industry ensuring a balanced feeding of animals to obtain quality meat [28]. During 2017-2018 in Ukraine other trends were observed than in the world.

According to the State Statistics Committee of Ukraine [29], in 2018 the lowest production of compound feed over the past 7 years has achieved. Thus, only cattle had a slight increase $(+3.7 \%)$ accounted 592 thousand tons, but the largest share was determined for compound feed for farm poultry - more than $40 \%$ (Figure 1). In general, the other three positions (poultry, pigs and "not included in other categories"), the trend of production was currently negative.

According to researchers, the production of compound feeds by 2030 will reach 20 million tons per year [28]. However, to date, imports of compound feeds and feed additives represent a significant share of the industry. Thus, in 2017, almost 32.9 million $\mathrm{kg}$ of feed amino acids, 35.9 million $\mathrm{kg}$ of feed phosphates, 2.8 million $\mathrm{kg}$ of vitamins, 36,3 million $\mathrm{kg}$ of feed additives were imported to Ukraine [30].

It is a well-known fact that the limiting factor in the development of poultry and pig breeding industries is the inability of animals to rapidly digest nutrients concentrated in compound feed [31, p. 64]. Therefore, to obtain a 


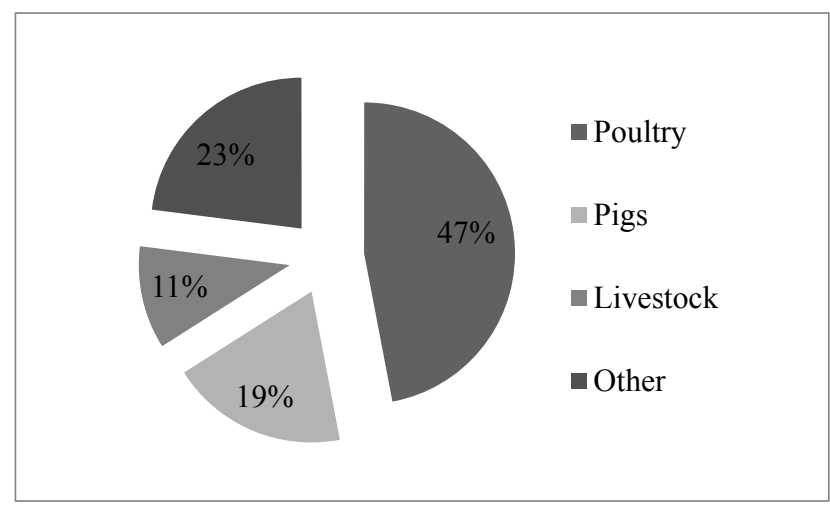

\section{Figure 1. Structure of compound feed production for farm animals in Ukraine in 2018 [29]}

healthy poultry when using compound feed rationally, one must concentrate on the physiology of the animal itself and its needs. Thus, special attention in the diet of poultry should be paid attention to sufficient protein content, essential amino acids (lysine, methionine) and available carbohydrates, i.e., fast digestible feeds $[32$, p. $227 ; 33$, p. $8 ; 34$, p. 395]. A complete diet in pig feeding should include protein and a limited amount of fiber fetlock $[35$, p. 126], because pigs have a single ventricle that does not have the enzymatic ability to hydrolyze it [36, p. $149 ; 37$, p. 89; 38, p. 47].

In this regard, protein-vitamin supplements, veterinary drugs for preventive and therapeutic purposes, mainly antibiotics, probiotics, and feed additives of mineral origin are used in the diet of farm animals [39, p. 92; 40, p. 95; 41, p. 460].

The European Association of Specialty Feed Ingredients and their Mixtures (FEFANA) identifies five main groups of additives [42]: technical additives that directly affect feed, such as organic acids; sensory additives affecting the consumption of feed, such as aromatizing agents; nutritional supplements that provide the necessary level of amino acids, vitamins and trace elements in the diet; zootechnical additives that improve the use of nutrients such as enzymes, coccidiostats and histomonostats.

Knowledge of the characteristics of digestion and metabolism in farm animals is crucial in improving its productivity. The main regulators of the 
digestive system include feed enzymes, feed antibiotics, probiotics and prebiotics. They have a different biological nature and, accordingly, different primary mechanisms of action. However, they all affect the health and productivity of the animal equally, namely by regulating the microbial population in the gastrointestinal tract [43, p. 153].

In countries with high hygiene requirements for livestock products, the use of feed antibiotics is completely forbidden or severely restricted. In the search for alternatives, experts have paid more attention to feed enzymes, probiotics and prebiotics [44; 45, p. 511; 46, p. 12].

Thus, it has been established that in recent times the problem based on necessity of introduction of resource-saving technologies of keeping and feeding of animals is becoming more and more frequent in agriculture. One of the directions in its solution is possible to use various additives and premixes, enzyme preparations, protein-vitamin supplements. But now the rational feeding of farm animals is considered the using of organic alga named chlorella.

\subsection{Chemical composition of chlorella as critical factor of using it in feeding of farm animals}

The only real method to produce the most complete feeding in animal husbandry is to supplement existing diets with products of natural origin, which also has a wide range of biologically valuable substances in their easily digestible form. Important here is not only the value of the product itself, but also its cost, as well as the availability of biotechnology in relation to livestock conditions.

The habitat of chlorella is usually freshwater reservoirs, where this microscopic alga, possessing a large stock of chlorophyll and a complex of rare nutrients, participates in the process of photosynthesis, absorbing carbon dioxide, saturating the air with oxygen, forming a green precipitate, and in rivers and lakes it is suspended [47, p. 510]. At present, industrial production of chlorella is increasing through its cultivation in phytobioreactors [48, p. 398].

Some scientists suggest that the total protein content of mature chlorella is $42-58 \%$ of dry biomass $[49$, p. 55]. Chlorella protein is superior in quality to known plant proteins, as it contains all the necessary amino acids, including essential ones [50]. The content of amino acids in chlorella $(\mathrm{g} / \mathrm{kg}$ air-dry mat- 
ter) consists of glutamic acid 31,84; asparagine 25.66; leucine 21.68; alanine 20.13; valine 17.58; glycine 17.02; threonine 13.66 (Table 1) [50, p. 135-136].

Table 1

\section{Chemical composition and nutrition of chlorella}

\begin{tabular}{|c|c|}
\hline \multicolumn{2}{|c|}{ The biochemical composition of chlorella,\% } \\
\hline Protein & 55 \\
\hline Lipids & 12 \\
\hline Carbohydrates & 25 \\
\hline Ash & 8 \\
\hline \multicolumn{2}{|c|}{ Content of aminoacids in chlorella, $\mathrm{g} / \mathrm{kg}$} \\
\hline Glutamic acid & 13,84 \\
\hline Aspartic acid & 25,66 \\
\hline Leucine & 21,68 \\
\hline Alanine & 20,13 \\
\hline Valine & 17,58 \\
\hline Glycine & 17,02 \\
\hline Threonine & 13,66 \\
\hline Phenylalanine & 12,06 \\
\hline Serine & 11,60 \\
\hline Isoleucine & 11,30 \\
\hline Proline & 9,78 \\
\hline Lysine & 8,78 \\
\hline Tyrosine & 8,25 \\
\hline Arginine & 8,17 \\
\hline Cystine & 7,53 \\
\hline Tryptophan & 5,11 \\
\hline Meteonin & 4,82 \\
\hline Histidine & 1,51 \\
\hline \multicolumn{2}{|c|}{ Content of some vitamins, $\mathrm{mcg} / \mathrm{g}$} \\
\hline Carotene & 1341 \\
\hline Tocopherol & 180 \\
\hline Nicotinic acid & 140 \\
\hline Riboflavin & 7,0 \\
\hline Pyrodixine & 5,3 \\
\hline Thiamine & 4,2 \\
\hline $\mathrm{D}$ & 1,0 \\
\hline B12 & 0,8 \\
\hline
\end{tabular}


Due to the chlorella protein contains all the essential aminoacids, its nutritional value is 2 times greater than the value of soy protein: $1 \mathrm{~kg}$ of chlorella is equivalent to $4-5 \mathrm{~kg}$ of soy [51, p. 46]. By adding 5-7 $\mathrm{kg}$ of dry matter content of chlorella to 1 ton of grain, its biological value increases by 1.5 times. In terms of calorie content, chlorella is equivalent to chocolate, and its protein is equivalent to that of milk powder [52, p. 88].

Chlorella also has an extremely strong cell wall, consisting mainly of a layer of chitosan, cellulose, hemicellulose, proteins, lipids and minerals $[53$, p. 630]. The composition of cell wall sugars is a mixture of rhamnose, galactose, glucose, xylose, arabinose, and mannose (Table 2). According to studies [54, p. 3825], the main saccharide of chlorella is rhamnose.

Table 2

The content of saccharides of the cell wall of chlorella [54]

\begin{tabular}{|c|c|}
\hline Saccharides & $\%$ \\
\hline rhamnose & $45-54$ \\
\hline arabinose & $2-9$ \\
\hline xylose & $7-19$ \\
\hline mannose & $2-7$ \\
\hline galactose & $14-26$ \\
\hline glucose & $1-4$ \\
\hline
\end{tabular}

The amount of vitamins, both in cells and in the culture medium, varies basically depends on the growing conditions and the phase of algae development [55, p. 18]. The macroelements and trace elements that are part of the chlorella include: phosphorus, calcium, potassium, magnesium, zinc, iron, cobalt, manganese, rubidium, zirconium and others [56, p. 301].

Consequently, chlorella has the great biological importance according to its chemical composition. Improving the health of farm animals, increasing their resistance by chlorella using in feeding can become a prerequisite for the production of livestock and poultry products of high quality.

\subsection{The physiological and productive action of chlorella in feeding of farm animals}

The issue of the impact of the use of chlorella in feeding of animals was addressed by many soviet scientists, such as Bogdanov N., Gafarov S., Mu- 
zafarov A., Melikhov V., Shatskikh E., Boyarintseva G., foreign including Kotrbáček V., Kang HK, Salim HM, Janczyk, P. and others. Recent investigations by Ukrainian scientists on the effects of chlorella as a feed additive in feeding of farm animals have not been found generally.

The physiological and productive effect of chlorella in feeding of farm animals is reflected to the indices of live weight gain, animal body resistance, reproductive functions, and the chemical composition of meat.

Expanding the study of valuable substances of chlorella algae has led to the search for new forms of its application. Thus, Muzafarov A. emphasizes that dry biomass of chlorella is worse absorbed by animals, so chlorella in the form of a suspension is better for animals [57, p. 114]. Sprug Y. considered that chlorella in the form of liquid has advantages, as animals consume not only the biomass of cells, but also the products of their vital activity contained in the solution [58, p. 38]. The optimal density of chlorella suspension for feeding to farm animals is 50-60 million cells in $1 \mathrm{ml}$. Consequently, a positive effect of the inclusion of chlorella in the main diet of animals in the form of suspension, dry biomass and aqueous extract was found to increase their productivity.

There are many studies of information on the effectiveness of the use of chlorella in the diet of farm poultry to increase their live weight, including the feeding of broiler chickens and ducks in the world modern scientific sources. Thus, Ahmedkhanova R. and Hamid N. investigated the effect of chlorella with the enzyme cellovyridine G3x on broiler chickens. They found an increase of the live weight by $5.75 \%$, improved conservation by $5.0 \%$ and reduced feed consumption by $6.54 \%$, compared with the control group [59, p. 76]. Scientists from Czechoslovakia have found a significant increase of the phagocytic activity of leukocytes of broiler chickens in response to the enrichment of chlorella feed by $0.5 \%$ [60, p. 327]. Duck feed based on 0.2 and $0.3 \%$ of chlorella led to improved nutrient use by these animals and also their mortality was reduced.

Gafarov S., Shatskikh E. and Boyaryntseva G. studied the increment of piglets number which were drinking chlorella suspension. At the end of the research, the scientists obtained the following results: one month after feeding the suspension of chlorella the live weight of the piglets was higher than in the control group by $7.6 \%$, and the average daily increment was increase by $16 \%[61$, p. 17]. Other scientists also confirmed in their 
own work that adding of algae to feeding of piglets had led to increasing of their weight.

Another investigation showed depending on the amount of suspension, the weight of the experimental calve group compared with the control group may be greater by $25-40 \%$, that were 5 and 6 months of age. Then the calves were weighed at 9 months of age and the difference in weight was already $50 \%$, which indicates the prolonged action of the chlorella suspension [62, p. 65].

Also experiments were conducted to determine the effect of chlorella suspension for 50 days on the productivity of dairy cows by soviet scientists. At the end of the study, it was found that the milk yield of the control group of cows was $1070 \mathrm{~kg}$, and in the experimental group $-1194 \mathrm{~kg}$, which is $124 \mathrm{~kg}$ more [63, p. 1746].

It was found that nutrient uptake was increased, fecal $\mathrm{NH}_{3}$ and $\mathrm{H}_{2} \mathrm{~S}$ content and fecal gas emissions were reduced when hog fattening with adding $0.1 \%$ of chlorella was conducted. In the gut microbiota of pigs, a higher content of Lactobacillus microorganisms and a lower content of Escherichia coli were also determined. These studies show that chlorella, even at low concentrations, as a feed additive for animals, can have a positive effect and is probably associated with an improvement in the taste quality of feeds, as well as a higher digestibility of minerals [64, p. 333].

In animal technology, hematological studies are often used to measure the degree to which animals meet nutritional requirements [65, p. 25]. Thus, not only the calculation of the total number of leukocytes, but also the determination of the percentage of individual forms of white blood cells, namely the leukocyte formula, is important in assessing the physiological state of the animal body [66, p. 45]. The decrease in lymphocyte content in peripheral blood in pigs makes compensation for a simultaneous increase in its phagocytes (neutrophils and monocytes). Consequently, the introduction of chlorella into the diet promotes the process of hematopoiesis in the red bone marrow, which to some extent contributes to the enhancement of the body's defenses of pigs.

The reproductive functions of animals play an important role in the procreation of the species, thereby providing the required amount of meat. Studies show that using chlorella as a feed additive for feeding roosters allowed to increase the activity of their sperm by $1.2 \%$, the volume of ejaculate - by $8.5 \%$, the sperm concentration by $4.7 \%$. Egg fertilization was increased by $1.2 \%$, and numbers of young animals were raised by $3.8 \%[67, \mathrm{p} .33]$. The 
feeding biologically active additives of chlorella to sows in the volume of 1 1 per head as part of the main daily diet for 30 days before farrowing and for 28 days after it contributed to the increase of the number of live piglets at birth per 1 sow by $25.0 \%$. In addition, survivability of piglets aged 28 days increased by $38.2 \%$, the live weight of 1 pig on the 28 th life day increased by $6.8 \%$, the gross weight of the young piglets increased by $49.1 \%$ [68, p. 112]. Depending on the amount of chlorella suspension for feeding sows per 1 kilogram of live weight during their preparation for fertilization contributed to the increase of sexual hunting of young pigs by $5-30,0 \%$; fertilization of young pigs by $2.6-11.1 \%$; their multiplicity - by $1.8-7.5 \%$ [69, p. 199].

Meat quality depends on many factors, such as the species, breed, sex, age of the animal and composition of feed [70, p. 180]. It is proven by science that today it is not possible to obtain meat possessing the high quality of any animal without the use of biologically complete diets, which include vitamins, minerals, amino acids, etc. The results of studies [71, p. 96] show that the use of chlorella suspension for feeding pigs increases the slaughter yield by $6,4 \%$ compared with the control group without the inclusion of algae in their diet, the output of pulp per kg of bone and muscle area raised by 20,77 and $10,52 \%$ respectively.

The data published by Park K. [72, p. 40] showed that using of chlorella in the feed for geese, their mass of meat increases and exceeds by $2.6-8.0 \%$ of geese meat in the control group without the addition of microalgae. In addition, the use of a suspension of chlorella in the composition of the feed for geese contributed to the increase in the amount of dry matter in their muscles of the chest and thigh.

The practical and scientific work of many researchers has shown that the use of chlorella, as an additional source of valuable substances in the feeding of farm animals, can reduce the cost of maintaining them, including the cost of feed [73, p. 120]. Depending on the period of fattening, the species, the sex of the animals, it is possible to reduce the amount of their feed by $1.5-12.5 \%$ if it includes chlorella.

Therefore, the mechanism of action of chlorella suspension is determined by its effect on all systems and functions of the animal body. Chlorella suspension is a natural probiotic, as it improves the quality of feed, it lacks feed toxins, which increases the live weight of farm animals, and can be used more widely in animal production. 


\subsection{Analysis of chlorella use as a source of pigments and trace elements for farm animals}

According to a published global report, the global carotenoid market reached 1.3 billion American dollars at the end of 2017 [74], explained by increased consumer awareness of the health benefits offered by various carotenoids and the transition to healthy and natural foods. A considerable amount of carotenoids also contain microalgae, in particular chlorella.

The composition of the microalgae of chlorella is not limited by the high content of protein, vitamins and trace elements. It also contains pigments, which synthesize the enzymes necessary for normal metabolism of living organisms. The most important pigment is chlorophyll, which is called "green gold" for the identity of its molecular structure of the hemoglobin molecule [75, p. 2811] (Figure 2). As known, chlorophyll provides significant support for the cardiovascular system, and also prevents the development of tumors, has antiseptic and regenerative properties. Some pigments of chlorella, as well as in terrestrial plants, have been proven to protect chlorophyll molecules from degradation and bleaching during heavy irradiation and oxygen [76, p. 1529].

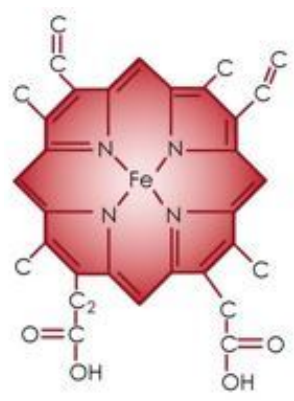

A

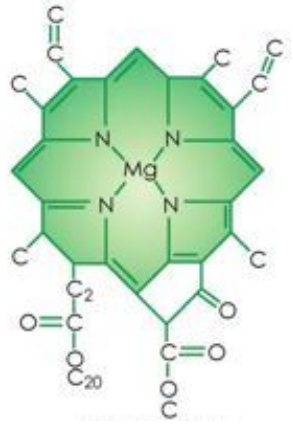

B

Figure 2. The molecule of hemoglobin (A) and chlorophyll (B)

Adverse conditions, such as a lack of biogenic elements, increasing concentrations of sodium chloride, lead to significant changes in the ratio of the pigment composition in algae cells towards predominance of carotenoids [77, p. 633]. Besides chlorophylls, which account $1-3 \%$ of the weight of 
dry algae cells [77, p. 631], chlorella contains a wide range of orange and yellow carotenoids, promoting photosynthesis, as well as protecting cellular structures from free radical damage and ultraviolet radiation.

The most valuable pigment found in chlorella is $\beta$-carotene, which mammalian cells cannot synthesize. Its concentration in chlorella is in the range of $0.1-0.2 \%$ [78, p. 145]. Known as provitamin A, $\beta$-carotene has been shown to prevent cancerous growth [79, p. 384].

The carotenoid pigmentation efficiency of the algae is extremely high. Thus, the enrichment of the feed mixture for laying hens with $2 \%$ concentration of dry chlorella increased the concentration of carotenoids in egg yolk fivefold [80, p. 287]. Similar studies have been confirmed even after using only $0.3 \%$ of dry chlorella in the poultry diet [81, p. 563]. A significant effect on the color of egg yolk was also found by Zheng et al. [82, p. 263] who had added 0.1 and $0.2 \%$ fermented chlorella to the chicken diet. Yolks of eggs of chickens, which are provided with chlorella as a feed additive, have an increased content of xanthophylls [82, p. 264]. Given the direct relationship between pigment intake and the protection of human vision from macular degeneration, eggs with high xanthophyll levels can be considered useful nutritional supplements [83, p. 199].

Scientists [71, p. 100] concluded that Beijing duck breast meat is characterized by a high amount of carotenoids, indicating a more yellowish tinge to meat than duck meat, the feeding of which had not involved the chlorella-based preparation. It was also found that the $\mathrm{pH}$ and water content of duck meat were directly proportional to the amount of chlorella used. According to a study by Park et al. [72, p. 42], the quality of edible meat can be determined by its $\mathrm{pH}$, which is related to water retention ability and color.

The effect of high- $\beta$-carotene extracted from chlorella has been studied on reproductive system of sows [84, p. 282]. The experimental group of sows was fed with synthetic $\beta$-carotene at a concentration of $100 \mathrm{mg}$ per day for animal during 1 month before the expected first fertilization, the other group - with synthetic $\beta$-carotene and dry chlorella powder in the amount of $1.5 \mathrm{~g}$ per animal. In both cases, the reproductive function of the sows improved significantly.

Laboratory studies have shown that heterotrophically cultured Chlorella $s p$. produces a significant amount of lutein, which plays an active role in delaying chronic diseases, preventing the development of cataracts and the 
progression of early atherosclerosis, and preventing blindness or reduced vision [85, p. 448]. The ability of heterotrophic growth in fermenters makes Chlorella sp. as potential alternative resource for commercial lutein production [86, p. 507].

Annual sales of Chlorella sp. exceed 38 billion American dollars [190], because algae are the major source of $\beta$-1,3-glucan [87, p. 500]. $\beta$-1,3-glucan can inhibit cancer cell growth in vivo by stimulating three important cytokines [88, p. 260]. Institute in Germany produces natural algae feed including Chlorella sp. and Arthrospira sp. for chickens called «Algrow» [89, p. 4].

Consequently, chlorella is used as a medicine in animal feed because it contains many important natural pigments.

Selenium (Se) and iodine (I) are important trace elements for human and animal health. The role of Se in the prevention of a number of diseases, including malignancies, thyroid gland dysfunction, cardiovascular disease, neurological diseases, aging, infertility and infections is proved by many scientific works [91, p. 645]. Iodine deficiency leads to serious disorders related to mammalian growth and development. Se and I play a significant role in the synthesis of thyroid hormones, which control the level of metabolism in almost all mammalian tissues [91, p. 400].

In European countries, soil and plants are mainly Se deficient [92, p. 60]. Therefore, several authors have grown chlorella as an additional source of Se or I in an inorganic medium enriched with selenium or iodide salts [93, p. 121]. In cell Se binds to proteins, $70 \%$ of which is represented by selenomethionine [93, p. 127]. Thus, a higher content of Se was found in eggs of chickens, whose diet contained chlorella that has been pre-enriched by Se [94, p. 1002]. Also, the high content of vitamin E in meat of chickens-boilers after feeding them with chlorella grown in selenium medium was determined [95, p. 166]. Se accumulation using feed additives of chlorella as a source of this trace element was also found in pig meat [96, p. 456].

Much of the enzyme glutathione peroxidase in mammals and humans consists of selenium-containing tetrameric proteins and glycoproteins. Low levels of glutathione peroxidase activity suggest that many diseases are likely to occur [97, p. 580], so the inclusion of Se foods in the diet is one of the important health benefits. The effect of the addition of selenium inorganic and organic forms (used inorganic selenite and an equal amount of organically bound Se in the chlorella biomass) on the activity of glutathione 
peroxidases was investigated in three groups of sheep and lambs [98, p. 44]. Thus, the content of Se in milk was increased, and the activity of glutathione peroxidase in the blood of sheep was found at a higher level when feeding consisted of selenium-containing chlorella. In addition, the fertility of lambs doubled when sheep were fed with chlorella-enriched of Se. Also enhanced development of immunoglobulin $\mathrm{G}$ in the serum of sheep and their generation is observed upon inclusion in the basic diet including Serich chlorella [99, p. 264].

Low content of I in soils, as well as Se, often leads to deficiency of this trace element in feeds made from plants [100, p. 380]. Typically, chlorella biomass contains low level of $I$, but the algae can also be enriched with iodine under specific conditions to sufficiently high level of $I$ in order to meet the dietary requirements fully. Chlorella enriched of $I$ was used in feeding for sows, resulting in the use of organically bound $I$ led to significantly higher levels of immunoglobulin A in the blood of these animals [101, p. 31].

Two weeks before parturation and after the scientists Baňoch T., Fajt Z., Kuta J., Kotrbáček V., Konečný R., Trávníček J., Svoboda M. [102, p. 516] analyzed the accumulation of I in serum in two groups of sows. Iodine at a concentration of $0.6 \mathrm{mg} / \mathrm{kg}$ in the form of salt KI and chlorella enriched by I were added in diet of first and second groups of sows respectively. $100 \mathrm{mg}$ of iodine per animal in the form of esters of iodized fatty acids were added to control group of sows. Lower levels of I, as well as hormone T3, were found in the serum of sows in the control group and piglets after 10 days of life.

Based on the results of studies [103, p. 958], the use of a suspension of chlorella grown on a nutrient medium of sodium selenite for feeding of piglets, had a positive effect on the live weight of pigs reared on meat, increased the protein content in meat, because Se activates protein metabolism and it is a part of more than 100 proteins.

The results of the above experiments show that chlorella is a new form of dietary supplement compared to traditional inorganic forms and it can be an effective source of pigments and trace elements including Se and I.

\subsection{Effect of chlorella use on the immune system of farm animals}

In the late 1980s and early 1990s, considerable attention was focused on the aqueous extract of chlorella cells, known as the Chlorella Growth Factor (CGF) containing free amino acids, peptides, glycoproteins, polyamines, 
phytohormones, minerals and other components [104, p. 590]. As is known, the aqueous extract of chlorella promotes tissue regeneration, growth and cell division, stimulates leukocyte production and phagocytic activity, and contributes to the production of antibodies that produce lymphocytes. The extracts also have probiotic activity, which influences the composition and activity of the microflora of the gastrointestinal tract [105, p. 1683].

Studies show that the use of an aqueous extract of chlorella has a positive effect not only on the immune system in broiler chickens, but also it can improve the quality of poultry meat [106, p. 229]. Other scientists have concluded that a dietary supplement for broiler chickens in the form of chlorella extract can enhance their productivity, increase the concentration of immunoglobulin A, metabolic nitrogen in the blood, and reduce ammonia emissions.

As noted earlier, chlorella allows the most complete use of feed by increasing its digestibility by $40 \%$, resulting in a significant increase in additional growth of animals [], which confirms the positive effect of microalgae on the animal body in general. Thus, the introduction of this feed additive in the diet of pigs contributed to the reduction of energy feed units and exchange energy per $1 \mathrm{~kg}$ gain by $15-20 \%$ [107, p. 1120], the cost of digestible protein per $1 \mathrm{~kg}$ gain in young pigs also tended to reduce by $10-12 \%[108$, p. 18], the content of erythrocytes increased by $28,3-32,1 \%$, the amount of glucose increased to $40,7-45 \%$ in comparison with the control, the content of total calcium and inorganic phosphorus in the blood increased an average by $1,5-2$ times [109, p. 23].

In the 1950 's, the Carnegie Institution in Washington explored and cultivated the microalgae of chlorella to reduce $\mathrm{CO}_{2}$ emissions. Today, Japan is the world leader in the use of chlorella and people of this country utilize it for treatment [110, p. 660], because it has been proven that chlorella has immunomodulatory and anticancer character. It has also been noted in medical practice that these microscopic algae are an effective tool in the control of anemia. In addition, chlorophyll which is one of the main pigments of chlorella provides significant support to the cardiovascular system, and prevents the development of tumors, has antiseptic and regenerative properties. Also chlorella synthesizes a natural antibiotic named «chlorellin» that successfully destroys pathogenic microflora.

It is especially necessary to note the effect on the animal body of the alkaline media of chlorella. Acidic environment allows fungi and pathogenic 
microflora to develop rapidly inside animal organism. In the reconstituted suspension of chlorella in an alkaline medium, fungi die. The growth factor contained in chlorella by 4 times accelerates the growth of natural microflora. As a result, work of the animal digestive tract normalizes. Due to the rich content of chlorophyll, the animal's body is able to defeat diseases of various etiologies, both non-infectious and infectious, including viral.

Therefore, chlorella has a wide range of biological activity, and in addition its use as a feed additive in diet of farm animals can increase resistance to infectious diseases, normalize metabolism, improve the function of the digestive system, and remove toxins from the body.

\section{Conclusions}

Based on previous investigations microalgae of chlorella as vitamin-feed and prophylactic additive is common used because its composition contains various biologically active substances. Introduction of chlorella in the diet of farm animals helps to improve their physiological and immune status due to the high content of proteins, lipids, amino acids, vitamins, minerals and others.

Also, the biological value of chlorella in feeding farm animals is the presence of pigments, carotenoids, which have a positive effect on their health and quality of food produced from these animals. Many scientists have noted the effectiveness of the use of feed additives of chlorella as a source of accumulation of $S e$ and $I$, which are important trace elements for the full life of both animals and humans.

Complementing the diets, chlorella, due to its rich composition, has a pronounced therapeutic prophylactic and immunostimulating effect on the body of animal. The use of chlorella suspension in animal rations allows farms to comprehensively solve the problem of increasing productivity in animal husbandry. From the point of view of biological value, the great importance of feeding by chlorella to animals is in the form of a suspension, and not in a dry or pasty form, because about half of its metabolites are in the culture medium itself. The suspension is drunk by the animal almost immediately, when the cell density rises to a certain value that completely avoids the loss of especially valuable substances in its composition, which are unavoidable during long periods of storage in other preparations. 


\section{References:}

1. Zhang Z.F., Kim I.H. (2014). Effects of multistrain probiotics on growth performance, apparent ileal nutrient digestibility, blood characteristics, cecal microbial shedding, and excreta odor contents in broilers. Poultry Science, vol. 93, no. 2 , pp. 364-70.

2. Saprykin V.O. (2011). Systema povnocinnoji ghodivli svynej kombikormamy na osnovi mono racioniv [System of complete feeding of pigs with compound feeds based on mono rations]. Nauk.-tekhn. bjul. In-tu tvarynnyctva NAAN, vol. 105, pp. 157-161.

3. Stein H.H., Lagos L.V., Casas G.A. (2016). Nutritional value of feed ingredients of plant origin fed to pigs. Animal Feed Science and Technology, vol. 218, pp. 33-66.

4. Ionov I.A., Tereshhenko O.V., Katerynych O.O. (2012). Perspektyvna proghrama «Rozvytok ghaluzi ptakhivnyctva do 2020 roku» [Prospective Program "Poultry Industry Development by 2020"]. Efektyvne ptakhivnyctvo, vol. 10, pp. 12-22.

5. Lange C, Pluske J., Gong J. (2010). Strategic use of feed ingredients and feed additives to stimulate gut health and development in young pigs. Livestock Science, vol. 134, pp. 124-134.

6. Heo J.M., Kim J.C., Hansen C.F. (2010). Feeding a diet with decreased protein content reduces both nitrogen content in the gastrointestinal tract and postweaning diarrhea, but does not affect apparent nitrogen digestibility in weaner pigs challenged with an enterotoxigenic strain of Escherichia coli. Animal Feed Science and Technology, vol. 160, pp. 148-159.

7. Morris H.J., Almarales A., Carrillo O., Bermudez R.C. (2008). Utilisation of Chlorella vulgaris cell biomass for the production of enzymatic protein hydrolysates. Bioresour Technology, vol. 99, pp. 7723-9.

8. Safi C., Charton M., Pignolet O., Silvestre F., Vaca-Garcia C., Pontalier P.-Y. (2013). Influence of microalgae cell wall characteristics on protein extractability and determination of nitrogen-to-protein conversion factors. Journal of Applied Phycology, vol. 25, pp. 523-9.

9. Bogdanov N.I. (2004). Ispol'zovanie khlorelly v ratsione sel'skokhozyaystvennykh zhivotnykh [The use of chlorella in the diet of farm animals]. Doklady Rossiyskoy akademii sel'skokhozyaystvennykh nauk, vol. 1, pp. 34-36.

10. Safi C., Charton M., Pignolet O., Pontalier P-Y., Vaca-Garcia C. (2013). Evaluation of the protein quality of Porphyridium cruentum. Journal of Applied Phycology,vol. 25, pp. 497-501.

11. Ursu A-V, Marcati A., Sayd T., Sante-Lhoutellier V., Djelveh G., Michaud P. (2014). Extraction, fractionation and functional properties of proteins from the microalgae Chlorella vulgaris. Bioresour Technology, vol. 157, pp. 134-9.

12. Bajguz A. (2000). Effect of brassinosteroids on nucleic acids and protein content in cultured cells of Chlorella vulgaris. Plant Physiology and Biochemistry, vol. 38, pp. 209-15.

13. Rausch T. (1981). The estimation of micro-algal protein content and its meaning to the evaluation of algal biomass I. Comparison of methods for extracting protein. Hydrobiologia, vol. 78, pp. 237-51. 
14. Lordan S., Ross RP., Stanton C. (2011). Marine bioactives as functional food ingredients: potential to reduce the incidence of chronic diseases. Mar Drugs, vol. 9, pp. 1056-100.

15. Janczyk P, Franke H, Souffrant WB. (2007). Nutritional value of Chlorella vulgaris: effects of ultrasonication and electroporation on digestibility in rats. Animal Feed Science and Technology, vol. 132, pp. 163-9.

16. Servaites J.C., Faeth J.L., Sidhu S.S. (2012). A dye binding method for measurement of total protein in microalgae. Analytical Biochemistry, vol. 421, pp. 75-80.

17. Panahi Y., Pishgoo B., Jalalian H.R., Mohammadi E., Taghipour H.R., Sahebkar A. (2012). Investigation of the effects of Chlorella vulgaris as an adjunctive therapy for dyslipidemia: results of a randomised open-label clinical trial. Nutrition \& Dietetics, vol. 69, pp. 13-9.

18. Beijerinck M. (1890). Kulturversuche mit Zoochlorellen, Lichenengonidien und anderen niederen Algen. Botanische Ztg, vol. 48, pp. 729-756.

19. Yamamoto M., Fujishita M., Hirata A., Kawano S. (2004). Regeneration and maturation of daughter cell walls in the autospore-forming green alga Chlorella vulgaris (Chlorophyta, Trebouxiophyceae). Journal of Plant Research, vol. 117, pp. 257-64.

20. Harinder P.S. Makkar (2016). State-of-the-art on detoxification of Jatropha curcas products aimed for use as animal and fish feed: A review. Animal Feed Science and Technology, vol. 22, pp. 87-99.

21. Agricultural production - animals. the Eurostat online publication "Agriculture, forestry and fishery statistics". Retrieved from: https://ec.europa.eu/ eurostat/statistics- explained/index.php/Agricultural_production_-_animals

22. Zhu Y., Hassan Y.I., Watts C., Zhou T. Innovative technologies for the mitigation of mycotoxins in animal feed and ingredients - A review of recent patents. Animal Feed Science and Technology. 2016; 216: 19-29.

23. Abdollahi M.R., Zaefarian V.F. Ravindran (2018). Feed intake response of broilers: Impact of feed processing. Animal Feed Science and Technology, vol. 237, pp. 154-165.

24. Global Agricultural. Retrieved from: https://www.globalagriculture.org/ report-topics/meat-and-animal-feed.html

25. The Food and Agriculture Organization (FAO) of the United Nations. Retrieved from: http://www.fao.org/

26. Farm Animal Feed Production Industry in the US. IBIS World. Retrieved from: https://www.ibisworld.com/industry-trends/specialized-market-researchreports/life-sciences/animal-health/farm-animal-feed-production.html

27. The American Feed Industry Association. Retrieved from: https://www.afia.org

28. European food Safety Authority (EFSA). Retrieved from: https://www.efsa.europa.eu

29. Derzhavna statystyka Ukrajiny [State statistics of Ukraine]. Retrieved from: www.ukrstat.gov.ua/

30. Agro Press. Portal pro kormy ta ghodivlju siljsjkoghospodarsjkykh tvaryn i ptyci. Import kormovykh preparativ do Ukrajiny, 2017r [Portal about feed and feed of farm animals and poultry. Import of feed products to Ukraine, 2017]. Retrieved from: http://agro.press/ua/article/import-kormovykh-preparatov-v-ukraine--2017 
31. Stein H.H., Lagos L.V., Casas G.A. (2016). Nutritional value of feed ingredients of plant origin fed to pigs. Animal Feed Science and Technology, vol. 218 , pp. $33-66$.

32. Jaroshenko F.O. (2004). Ptakhivnyctvo Ukrajiny: stan, problemy i perspektyvy rozvytku. Kyiv: Aghrarna nauka. (in Ukrainian)

33. Burjak R.I. (2009). Tendenciji rozvytku ghaluzi ptakhivnyctva v umovakh transformaciji ekonomiky [Trends in the development of the poultry industry under conditions of economic transformation]. Suchasne ptakhivnyctvo, vol. 9-10, pp. 7-13.

34. Kessler E. (1984). Ageneral review on the contributions of chemotaxonomy to the systematics of green algae. Systematics of the green algae. Academic Press, pp. 391-407.

35. Lange C, Pluske J., Gong J. (2010). Strategic use of feed ingredients and feed additives to stimulate gut health and development in young pigs. Livestock Science, vol. 134, pp. 124-134.

36. Heo J.M., Kim J.C., Hansen C.F. (2010). Feeding a diet with decreased protein content reduces both nitrogen content in the gastrointestinal tract and postweaning diarrhea, but does not affect apparent nitrogen digestibility in weaner pigs challenged with an enterotoxigenic strain of Escherichia coli. Animal Feed Science and Technology, vol. 160, pp. 148-159.

37. Franco L.D., Fondevila M., Lobera M.B. (2005). Effect of combinations of organic acids in weaned pig diets on microbial species of digestive tract contents and their response on digestibility. Journal of Animal Physiology and Animal Nutrition, vol. 89, pp. 88-93.

38. Coffey R.D., Cromwell G.L. (2001). Use of spray-dried animal plasma in diets for weanling pigs. Pig News and Information, vol. 22, no 2, pp. 39-48.

39. Anadón A., Martínez-Larrańaga M.R., Martínez M.A. (2006). Probiotics for animal nutrition in the European Union, regulation and safety assessment. Regulatory Toxicology and Pharmacology, vol. 45, pp. 91-5.

40. Anadón A., Castellano V., Martínez-Larrañaga M.R. (2014). Regulation and guidelines of probiotics and prebiotics. In: Ötles S, editor. Probiotics and prebiotics in food, nutrition and health. Boca Raton: CRC Press, LLC Taylor \& Francis Group, pp. 91-113.

41. Plavnik I., Scott M.L. (1980). Effects of additional vitamins, minerals or brewers yeast upon leg weaknesses in broiler chickens. Poultry Science, vol. 59, pp. 459-64.

42. EU Association of Specialty Feed Ingredients and their Mixtures. Retrieved from: http://fefana.org/

43. Havenaar R. (1992). Probiotics: a general view. Lactic acid bacteria in health and disease. London: Elsevier Applied Science Publishers, pp. 151-70.

44. FAO (2002). Guidelines for the evaluation of probiotics in food. Report of a Joint FAO/WHO Working Group on Drafting Gidelines for the evaluation of probiotics in food. Ontario: Press Canada.

45. Hill C., Guarner F., Reid G. (2014). Sanders expert consensus document: the International Scientific Association for Probiotics and Prebiotics consensus 
statement on the scope and appropriate use of the term probiotic. Nature Reviews Gastroenterology \& Hepatology, vol. 11, pp. 506-14.

46. Markowiak P., Śliżewska K. (2018). The role of probiotics, prebiotics and synbiotics in animal nutrition. Gut Pathogens, pp. 10-21.

47. Ghirardi M.L., Zhang L., Lee J.W., Flynn T., Seibert M., Greenbaum E. (2000). Microalgae: a green source of renewable H(2). Trends Biotechnology, vol. 18 , pp. 506-11.

48. Temraleeva A.D., Myncheva E.V., Shherbakov D.Ju., Pynskyj D.L. (2013). DNK-shtrykhkodyrovanye zelenykh vodoroslej: Obzor [DNA Barcoding of Green Algae: Overview]. Aljghologhyja, vol. 23, no. 4, pp. 396-418.

49. S`kaloud P. (2014). Planktochlorella nurekis gen. et sp. nov. (Trebouxiophyceae, Chlorophyta), a novel coccoid green alga carrying significant biotechnological potential. Fottea, vol. 14, pp. 53-62.

50. Ursu A.V., Marcati A., Sayd T., Sante-Lhoutellier V., Djelveh G., Michaud P. (2014). Extraction, fractionation and functional properties of proteins from the microalgae Chlorella vulgaris. Bioresour Technology, vol. 157, pp. 134-9.

51. Crossman D.J., Clements K.D., Cooper G.J.S. (2000). Determination of protein for studies of marine herbivory: a comparison of methods. Journal of Experimental Marine Biology and Ecology, vol. 244, pp. 45-65.

52. Kuchitsu K., Oh-hama T., Tsuzuki M., Miyachi S. (1987). Detection and characterization of acidic compartments (vacuoles) in Chlorella vulgaris $11 \mathrm{~h}$ cells by 31P-in vivo NMR spectroscopy and cytochemical techniques. Archives of Microbiology, vol. 148, pp. 83-7.

53. Abo-Shady A.M., Mohamed Y.A., Lasheen T. (1993). Chemical composition of the cell wall in some green algae species. Biologia Plantarum, vol. 35, pp. 629-32.

54. Takeda H. (1988). Classification of Chlorella strains by cell wall sugar composition. Phytochemistry, vol. 27, pp. 3823-6.

55. Panahi Y., Pishgoo B., Jalalian H.R., Mohammadi E., Taghipour H.R., Sahebkar A. (2012). Investigation of the effects of Chlorella vulgaris as an adjunctive therapy for dyslipidemia: results of a randomised open-label clinical trial. Nutrition \& Dietetics, vol. 69, pp. 13-9.

56. Becerra G., Menolasina S., Salvador A. (1999). Supercritical fluid extraction and supercritical fluid chromatography of Vitamin E in pharmaceutical preparations. Journal of High Resolution Chromatography, vol. 22, pp. 300-2.

57. Muzafarov A.M., Taubaev A.M. (1984). Kul'tivirovanie i primenenie mikrovodorosley [Cultivation and use of microalgae]. Tashkent: Fan UzSSR.

58. Spruzh Ya. (1984). Ispol'zovanie khlorelly v ratsione. Kul'tivirovanie i primenenie mikrovodorosley v narodnom khozyaystve [The use of chlorella in the diet. Cultivation and use of microalgae in the national economy]. Tashkent: «Fan» UzSSR.

59. Akhmedkhanova R.R., Gamidov N.R. (2010). Ispol'zovanie gidrobionetov $\mathrm{v}$ kormlenii sel'skokhozyaystvennoy ptitsy [Use of aquatic organisms in feeding poultry]. Problemy razvitiya APK regiona, vol. 1, pp. 73-78.

60. Kotrbáček V., Halouzka R., Jurajda V, Knotková Z, Filka J. (1994). Enhancement of defence mechanisms in broilers after administration of biological feed supplements. Vet Med-Czech, vol. 39, pp. 321-328. 
61. Gafarov Sh.S., Shatskikh E.V., Boyarintseva G.G. (2010). Ispol'zovanie khlorelly v kormlenii porosyat [Use of chlorella in feeding piglets]. Agrarnyy vestnik Urala, vol. 11-2, pp. 16-17.

62. Jahn S., Sieber E., Sparborth D., Kühnel M. (2005). A little green helpmate. Neue Landwirtschaft, vol. 1, pp. 64-65.

63. Yan L., Lim S.U., Kim I.H. (2012). Effect of fermented Chlorella supplementation on growth performance, nutrient digestibility, blood characteristics, fecal microbial and fecal noxious gas content in growing pigs. Asian-Australasian Journal of Animal Sciences, vol. 25, pp. 1742-1747.

64. Taranu I., Marin D.E., Untea A., Janczyk P., Motiu M., Criste R.D., Souffrant W.B. (2012). Effect of dietary natural supplements on immune response and mineral bioavailability in pigments after weaning. Czech Journal of Animal Sciences, vol. 57, pp. 332-347.

65. Vikulina Gh.V. (2008). Dejaki pokaznyky obminu lipidiv syrovatky krovi porosjat riznogho viku [Some indicators of serum lipid metabolism of piglets of different ages]. Nauk. visnyk Ljviv. NUVMBT im. S. Z. Gzhycjkogho, vol. 10, no 37, pp. 22-26.

66. Petryakov V.V. (2009). Otsenka morfofiziologicheskikh pokazateley krovi i estestvennoy rezistentnosti organizma sviney [Assessment of the morphophysiological parameters of blood and the natural resistance of the organism of pigs]. Izvestiya Samarskoy gosudarstvennoy sel'skokhozyaystvennoy akademii, vol. 1, pp. 43-46.

67. Romashko A.K., Shalygo N., Manankina E., Erashevich V. (2015). Khlorella $\mathrm{v}$ ratsionakh ptitsy [Chlorella in the diets of poultry]. Veterinariya $i$ zhivotnovodstvo, vol. 10, pp. 32-36.

68. Yakhtanigova Zh.M., Fedorchuk E.G., Miroshnichenko I.V., Naval'neva I.A. (2016). Ispol'zovanie suspenzii khlorelly v kormlenii svinomatok do i posle ikh oporosa [The use of chlorella suspension in feeding sows before and after their farrowing]. Innovatsii v APK: problemy i perspektivy, vol. 2, no 10, pp. 109-114.

69. Pokhodnya G.S., Malakhova T.A. (2015). Povyshenie vosproizvoditel'noy funktsii u molodykh svinomatok za schet vvedeniya $\mathrm{v}$ ikh ratsion suspenzii khlorelly [Increase of reproductive function in young sows by introducing chlorella suspension into their diet]. Veterinariya i zootekhniya, pp. 196-200.

70. Pivtorak Ja.I., Semchuk I.Ja. (2009). Vyvchennja vplyvu na jakistj produkciji vykorystannja u racionakh vidghodiveljnogho molodnjaku svynej biologhichno aktyvnykh dobavok [Study of the influence on the quality of products of use in the diets of fattening pigs of biologically active additives]. Naukovyj visnyk Ljvivsjkogho NUVMBT im. S.Z. Ghzhycjkogho, vol. 11, no. 41, pp. 178-181.

71. Oh, S.T., Zheng, L., Kwon, H.J., Choo, Y.K., Lee, K.W., Kang, C.W., An, B.K. (2015). Effects of dietary fermented Chlorella vulgaris (CBT $\left.{ }^{\circledR}\right)$ on growth performance, relative organ weights, cecal microflora, tibia bone characteristics, and meat qualities in Pekin ducks. Asian-Australasian Journal of animal sciences, vol. 28 , no. 1, pp. $95-101$.

72. Park K.K., Park H.Y., Jung Y.C., Lee E.S., Yang S.Y., Im B.S., Kim C.J. (2005). Effects of fermented food waste feeds on pork carcass and meat quality properties. Korean Journal of Food Science and Technology, vol. 37, pp. 38-43. 
73. Madeira M. S., Cardoso C., Lopes P. A., Coelho D., Afonso C., Bandarra N. M., Prates, J. A. (2017) Microalgae as feed ingredients for livestock production and meat quality: A review. Livestock Science, vol. 205, pp. 111-121.

74. Global Industry Analysts, Inc. Retrieved from: http://www.strategyr.com/ Carotenoids_Market_Report.asp/

75. Munoz R., Guieysse B. (2006). Algal-bacterial processes for the treatment of hazardous contaminants: a review. Water Resarch, vol. 40, pp. 2799-815.

76. Gonzalez L.E., Bashan Y. (2000). Increased growth of the microalga Chlorella vulgaris when coimmobilized and cocultured in alginate beads with the plantgrowth-promoting bacterium Azospirillum brasilense. Applied and Environmental Microbiology, vol. 66, pp. 1527-31.

77. Illman A.M., Scragg A.H., Shales S.W. (2000). Increase in Chlorella strains calorific values when grown in low nitrogen medium. Enzyme and Microbial Technology, vol. 27, pp. 631-5.

78. Berková E., Doucha J. (1970). Chlorophyll synthesis and photosynthesis in synchronous cultures of Scenedesmus quadricauda. In: Nečas J., Lhotský O. Annual Report Algolog Lab Třebon̆ for 1969, pp. 141-150.

79. Becker E.W. (2004). The nutritional value of microalgae for aquaculture. Handbook of microalgal mass cultures. CRC Press Inc. Boca Raton, Florida.

80. Ben-Amotz A., Rachmilewich B., Greenberg S., Sela M., Weshler Z. (1996). Natural $\beta$-carotene and whole body irradiation in rats. Radiation and Environmental Biophysics, vol. 35, pp. 285-288.

81. Mader P., Mikolášek A., Lidická M., Nováková V., Hartlová L., Staněk J. (1984). Algae as a natural source of carotenoids in laying hen fed mixture. Zivoč Výr, vol. 29, no. 6, pp. 557-567.

82. Zheng LST Oh, Jeon J.Y., Moon B.H., Kwon H.S., Lim S.U., An B.K., Kang C.W. (2012). The dietary effects of fermented Chlorella vulgaris (CBT) on production performance, liver lipids and intestinal microflora in laying hens. AsianAustralasian Journal of Animal Sciences, vol. 25, pp. 261-266.

83. Kotrbáček V., Skřivan M., Kopecký J., Pěnkava O., Hudečková P., Uhríková I., Doubek J. (2013) Retention of carotenoids in egg yolks of laying hens supplemented with heterotrophic Chlorella. Czech Journal of Animal Sciences, vol. 58, pp. 193-200.

84. Kotrbáček V., Doubek J., Offenbartl F., Holešovská Z., Doucha J. (2005). Reproductive function in sows-possibilities of their influencing. Veterinarstvi, vol. 55, pp. 280-283.

85. Shi X.-M., Chen F., Yuan J.-P., Chen H. (1997). Heterotrophic production of lutein by selected Chlorella strains. Journal of Applied Phycology, vol. 9, pp. $445-450$.

86. Zhang X.-W., Shi X.-M., Chen F. (1999). A kinetic model for lutein production by the green microalga Chlorella protothecoides in heterotrophic culture. Journal of Industrial Microbiology \& Biotechnology, vol. 23, pp. 503-507.

87. Yamaguchi K. (1997). Recent advances in microalgal bioscience in Japan, with special reference to utilization of biomass and metabolites: a review. Journal of Applied Phycology, vol. 8, pp. 487-502. 
88. Iwamoto H. (2004). Industrial production of microalgal cell-mass and secondary products - major industrial species Chlorella. Handbook of Microalgal Culture Biotechnology and Applied Phycology. Oxford: Blackwell Publishing Ltd.

89. Blaylock R.L. (2002). Yeast $\beta$-1,3-glucan and its use against anthrax infection and in the treatment of cancer. Journal of the American Nutraceutical Association, vol. 5, pp. 3-4.

90. Pulz O., Gross W. (2004). Valuable products from biotechnology of microalgae. Applied Microbiology and Biotechnology, vol. 65, pp. 635-648.

91. Thomson C.D. (2004). Assessment of requirements for selenium and adequacy of selenium status: a review. European Journal of Clinical Nutrition, vol. 58, pp. 391- 402 .

92. Trávníček J., Kroupová V., Konečný R., Staňková M., Štastná J., Hasoňová L., Mikulová M. (2010). Iodine status in ewes with the intake of iodine enriched alga Chlorella. Czech Journal of Animal Sciences, vol. 55, pp. 58-65.

93. Sager M. (2006). Selenium in agriculture, food, and nutrition. Pure and Applied Chemistry, vol. 78, pp. 111-133.

94. Doucha J., Lívanský K., Kotrbáček V., Zachleder V. (2009). Production of Chlorella biomass enriched by selenium and its use in animal nutrition: a review. Applied Microbiology and Biotechnology, vol. 83, pp. 1001-1008.

95. Skřivan M., Šimáně J., Dlouhá G., Doucha J. (2006). Effect of dietary sodium selenite, Se-enriched yeast and Se enriched Chlorella on egg Se concentration, physical parameters of eggs and laying hen production. Czech Journal of Animal Sciences, vol. 51, pp. 163-167.

96. Ševčíková S, Skřivan M, Dlouhá G, Koucký M. (2006). The effect of selenium source on the performance and meat quality of broiler chickens. Czech Journal of Animal Sciences, vol. 51, pp. 449-457.

97. Svoboda M., Saláková A., Fait Z., Kotrbáček V., Ficek R., Drábek J. (2009a). Efficacy of Se-enriched alga (Chlorella spp.) and Se-enriched yeast on tissue selenium retention and carcass characteristics in finisher pigs. Acta Veterinaria Brno, vol. 78, pp. 579-587.

98. Trávníček J., Písek L., Herzig I., Doucha J., Kvíčala J., Kroupová V., Rodinová H. (2007). Selenium content in blood serum and urine of ewes receiving selenium-enriched unicellular alga Chlorella. Veterinární medicína, vol. 52, pp. 42-48.

99. Rodinová H., Kroupová V., Trávníček J., Staňková M., Písek L. (2008). Dynamics of IgG in blood serum of sheep with different selenium intake. Veterinárni medicina, vol. 53, pp. 260-265.

100. Herzig I., Suchy P. (1996). Contemporary view of the importance of iodine for animals. Veterinární medicína, vol. 41, pp. 379-386.

101. Kotrbáček V., Doucha J., Offenbartl T. (2004). Use of Chlorella as a carrier of organic-bound iodine in the nutrition of sows. Czech Journal of Animal Sciences, vol. 49, pp. 28-32.

102. Baňoch T., Fajt Z., Kuta J., Kotrbáček V., Konečný R., Trávníček J., Svoboda M. (2011). Utilization of iodine from different sources by sows and their progeny. Neuro Enocrinology Letters, vol. 32, pp. 510-517. 
103. An H.J., Rim H.K., Lee J.H., Seo M.J., Hong J.W. (2008). Effect of Chlorella vulgaris on immune-enhancement and cytokine production in vivo and in vitro. Food Science and Biotechnology, vol. 17, pp. 953-958.

104. An H.J., Rim H.K., Jeong H.J., Hong S.H., Um J.Y. (2010). Hot water extracts of Chlorella vulgaris improve immune function in protein-deficient weanling mice and immune cells. Immunopharmacol Immunotoxicol, vol. 32, pp. 585-592.

105. Buono S., Langellotti A.L., Martello A., Rinna F., Fogliano V. (2014). Functional ingredients from microalgae. Food Function, vol. 5, pp. 1669-1685.

106. Guzmán S., Gato A., Calleja J.M. (2001). Antiinflammatory, analgesic and free radical scavenging activities of the marine microalgae Chlorella stigmatophora and Phaeodactylum tricornutum. Phytotherapy Research, vol. 15, pp. 224-230.

107. Suárez E.R., Kralovec J.A., Grindley T.B. (2010). Isolation of phosphorylated polysaccharides from algae: the immunostimulatory principle of Chlorella pyrenoidosa. Carbohydrate Research, vol. 345, no. 9, pp. 1190-204.

108. Gamko L., Podol'nikov M.V., Ufimtsev D.K. (2008). Perevarimost' i transformatsiya $\mathrm{v}$ produktsiyu pitatel'nykh veshchestv korma pri skarmlivanii molodnyaku sviney mikrovodorosli [Digestibility and transformation of feed nutrients into production by feeding microalgae to young pigs]. Svinovodstvo, vol. 3, pp. 16-18.

109. Gamko L.N., Podol'nikov M.V., Ufimtsev D.K. (2008). Vliyanie suspenzii khlorelly na prirosty sviney na otkorme [The effect of chlorella suspension on growths of fattening pigs]. Zootekhniya, vol. 11, pp. 23-24.

110. Kitada K., Machmudah S., Sasaki M., Goto M., Nakashima Y., Kumamoto S. (2009). Supercritical $\mathrm{CO}_{2}$ extraction of pigment components with pharmaceutical importance from Chlorella vulgaris. Journal of Chemical Technology \& Biotechnology, vol. 84, pp. 657-61. 